\title{
Cognitive performance of individuals with animal hoarding
}

\author{
Luis Henrique Paloski ${ }^{1,2}$, Elisa Arrienti Ferreira ${ }^{1}$, Dalton Breno Costa ${ }^{3}$, Camila Rosa de Oliveira², \\ Carmen Moret-Tatay ${ }^{4}$ (D) and Tatiana Quarti Irigaray ${ }^{1 *}$
}

\begin{abstract}
Background: The purpose of this study was to characterize the cognitive performance of individuals with animal hoarding.

Methods: This is a cross-sectional study, in which 33 individuals between the ages of 29 to $84(M=61.39$; SD $=$ 12.69) with animal hoarding have been assessed. The participants completed a neurocognitive battery including measures of general cognitive functioning, visual memory and organization, verbal fluency, and verbal reasoning.

Results: Data suggest that individuals with animal hoarding have high rates of cognitive deficits related to visual memory and verbal reasoning.

Conclusions: Based on the performance tests used, we can suggest the existence of cognitive difficulties related especially to the executive functions of individuals with animal hoarding in this sample.
\end{abstract}

Keywords: Animal hoarding, Cognitive profile, Executive functions

\section{Introduction}

Animal hoarding is considered a new field of research and there are few empiric studies on the topic. It is defined by the accumulation of a large number of animals and a failure to provide minimal standards of nutrition, sanitation and veterinary care (American Psychiatric Association 2014). Additionally, there is the subject's inability to act on the deteriorating conditions of the animals (starvation, disease, death) and a denial or downplaying of the hoarding-derived issues both for the animals and people sharing the same space $[7,8,12]$.

In DSM-5, the animal hoarding is treated as a special manifestation of the Hoarding Disorder and some studies discuss these differences $[10,35]$. It is different mostly given the animal hoarding' poorer insight [1]. The animal hoarding differs from the object hoarding from its nature, because animals require more interaction and attention than objects. Also, the majority of individuals who hoards animals do not present the behavior of hoarding objects [9].

\footnotetext{
* Correspondence: tatiana.irigaray@pucrs.br

${ }^{1}$ Pontifícia Universidade Católica do Rio Grande do Sul - PUCRS, Av. Ipiranga, 6681, Building 11, 9th floor, Porto Alegre, RS CEP 90619-900, Brazil Full list of author information is available at the end of the article
}

Individuals who accumulate animals may have their cognitive abilities compromised [4, 19, 37]. Likewise, it is believed that animal hoarding may stem from cognitive deficits, possibly more severe ones, given the unhealthier environment in which individuals and animals live (American Psychiatric Association 2014).

Studies suggest that attention deficit disorders are found in hoarding disorders, and it is estimated that $28 \%$ of individuals fulfill the criteria for the Attention Deficit Disorder/Hyperactivity subtype $[6,10,11]$. Other studies suggest low levels of alternating attention [14] and selective attention [19] are related to hoarding disorders.

In addition to attention, other cognitive functions are compromised in hoarding disorders, such as memory [12, 15], and so are executive functions [36]. Information processing and categorization and decision-making skills are also compromised [33].

Blom et al. [4] found a relationship between hoarding disorders and deficits in memory and decision-making skills. Moreover, deficits in terms of categorization, information processing speeds, and verbal memory were found as well [19]. Moshier et al., [22] point out that, although studies show perform below standard in neuropsychological tests in terms of working memory, focused

(c) The Author(s). 2020 Open Access This article is distributed under the terms of the Creative Commons Attribution 4.0 International License (http://creativecommons.org/licenses/by/4.0/), which permits unrestricted use, distribution, and 
attention, and executive performance tasks, such information is still insufficient for building a proper profile of individuals' cognitive performance.

Although this paper is on animal hoarding, no empiric studies looking into the cognitive performance of people with this characteristic were found. It is important to investigate cognitive abilities of animal hoarding in order to be possible to develop specific therapeutic interventions for this population [25]. Therefore, our literature review comprised studies on Hoarding Disorder. The main purpose of this study is to investigate the cognitive performance of animal hoarding. The core hypothesis of this study is that, given there are cognitive performance deficits in object accumulation, we infer cognitive deficits may be found in animal hoarding $[13,15,21,27]$.

\section{Method}

\section{Participants}

Seventy-five probable cases of animal hoarding were found from administrative proceedings filed in the city of Porto Alegre by the City Office for Animal Rights (SEDA, in the Portuguese acronym). The researchers visited 61 homes between August 2015 and May 2016. The team was allowed in by 48 people, 38 of whom accepted to take part in the study. The addresses to the other 14 homes were either not found by the team or the people had already moved.

We used the DSM-5 (American Psychiatric Association 2014) diagnostic criteria to define the people with Animal Hoarding. They are: (1) the accumulation of a large number of animals; (2) a failure to provide minimal standards of nutrition, sanitation, and veterinary care; (3) a failure to act on the deteriorating condition of the animals (eg, disease, starvation, death) and the environment (eg, severe overcrowding, extremely unsanitary conditions).

Out of the 38 people who agreed to participate, three did not meet the criteria required to be diagnosed with Animal Hoarding Disorder because their animals were in good health and nutrition conditions and the environment was suitable. Regarding this criterion, a report on each home visited and provided by SEDA veterinarians was used. One participant was excluded because of a speech impediment that prevented data from being collected. Another one was also excluded for being a schizophrenic.

\section{Instruments}

\section{Socio-demographic data form}

Comprised the age, gender, marital status, schooling, and income variables. We also investigated the number and species of animals in the home, as well as the time when hoarding began.

\section{Mini-mental state examination (MMSE)}

The MMSE is a general cognitive screen. It contains questions that evaluate time and space orientation, registration of three words, attention and calculation, recall of three words, language, and visuoconstructional ability. The Portuguese version translated by [3] was used. We used the cutoff point suggested in the study by Kochhann et al. [17] to characterize the participants with and without a deficit according to their schooling: 21 for the group of illiterates, 22 in the low schooling group (1-5 years of education), 23 in the mid-schooling group (611 years of education), and 24 in the highly educated group ( $\geq 12$ years of education). These values are based on the study by Kochhann et al. [17] among elderly people in southern Brazil. The study by Santos et al. [29] found a 0.80 Cronbach's alpha.

\section{Rey complex figures}

They are complex, geometric, abstract figures made of various parts. Figures must be copied and after 3 minutes drawn from memory [23, 24]. This test evaluates perception, visuoconstructional ability, and visual memory. Additionally, it makes it possible to evaluate planning, organization, problem-solving strategies, and motor function skills [26]. The Rey complex figure test shows good internal consistency, according to the Cronbach's alpha coefficient estimated at 0.86 when copying and 0.81 when drawing from memory [23].

\section{Semantic verbal fluency test - category animals}

In this test, participants are asked to produce as many animal species as possible over 1 minute. It is a measurement of executive functions which primarily evaluates verbal fluency. It also measures a person's ability to organize their thoughts and the strategies they use to find words. A participant's score is the total sum of animals listed in 1 minute, minus repeated words [32]. In the study by Santos [30], Cronbach's alpha was 0.74 .

\section{WASI - Wechsler abbreviated scale of intelligence similarities subtest}

WASI is a short test to measure intelligence and typically lasts 30 to $45 \mathrm{~min}$ on average. This study used only the Similarities subtest, whose main purpose is to measure verbal concept formation, abstract verbal reasoning, and general intellectual skills. The subtest shows good internal consistency, ranging from 0.84 to 0.96 [34].

\section{Data collection procedures}

The project was approved by the PUCRS Ethics Committee (CEP-PUCRS) under CAAE: 44489715.8.0000.53 36 . The participants were contacted via home visits, and those who accepted to take part in the study signed an informed consent form. Next, they individually answered 
the questionnaires. Participants were evaluated during home visits lasting 1 hour and a half, on average, by the project coordinator and team. The latter comprised psychologists and Psychology research undergrads trained beforehand to help administer the assessments used in this study.

The city of Porto Alegre, via SEDA, provided a list of 75 hoarding cases and their contact information, as well as a veterinary doctor and an inspector to accompany the researchers during their visits to participants. While the team evaluated the participants, the animals were assessed and treated by the veterinarians. In case an animal required some sort of specialized treatment, it was taken to the animal hospital upon the participants' permission. The Environmental Division at the Rio Grande do Sul State Attorney's Office (MPRS) provided transportation for PUCRS faculty and students upon prior scheduling. The interviews with the participants were conducted in the vehicle provided by the MPRS. The researchers took the necessary care to make the vehicle appropriate for the instruments application.

\section{Data analysis procedures}

The assessments were administered and graded according to their respective manuals or rules. The tests containing normative data for the Brazilian population were analyzed in terms of percentiles and $\mathrm{T}$ scores. The $\mathrm{T}$ scores were used only to identify whether the participant's performance was deficient or not. The $\mathrm{T}$ score is a standardized score and is verified by normative data.

The total Rey complex figure test scores were converted into percentiles according to the manual [24]. Then, they were reclassified into adequate and substandard performance, that is, percentiles from 50 to 100 were reclassified as adequate and from 10 to 40 as substandard. Gross verbal fluency test scores were converted into $\mathrm{Z}$ scores according to the participants' schooling [5], where $Z \geq-1.3$ scores were considered substandard performance [18]. The Similarities subtest was graded according to its manual [34]. First, gross scores were calculated. Then, they were converted into $\mathrm{T}$ scores according to the participants' age. Next, T scores were reclassified as follows: up to 50 adequate and $<50$ as substandard.

The information was organized and analyzed using a bank created through the Statistical Package for the Social Sciences (SPSS, version 17) software for Windows. The information was described by means of absolute $(n)$ and relative (\%) frequencies for qualitative variables, and by mean and standard deviation for quantitative variables. In order to present more detailed cognitive characteristics, participants were divided into two age groups (20-59 years and $60+$ years), corresponding to young and older adults.

\section{Results}

Table 1 shows sociodemographic and animal hoarding data of each participant.

Table 2 shows the description of socio-demographic profiles, incidence of psychopathological symptoms, and cognitive performance of adults with animal hoarding. The final sample comprised 33 people ranging in age between 29 and 84 years $(M=61.39 ; S D=12.69), 64 \%$ of whom were over 60 years old. Of the participants, $73 \%$ were female and $27 \%$ male, with schooling between one and 16 years $(M=9.39 ; S D=4.40)$. Income-wise, $75 \%$ earned between one and two minimum monthly salaries. It was found that $90 \%$ of participants were single and $51 \%$ lived on their own. The number of animals per home ranged between 3 to $101(M=41.12 ; S D=24.41)$, totaling 1357 animals, and the time in years that hoards animals ranged from 3 to 70 years $(M=23.09$; $S D=$ 15.98). No significant associations were found between number of animals and education $(r=.273, p=.124)$, age $(r=.052, p=.774)$, sex $\left(\mathrm{X}^{2}=.248, p=.619\right)$ and income $\left(\mathrm{X}^{2}=.010, p=.922\right)$. Also, the time that hoards animals did not present significant associations with schooling $(r=-081, p=.653)$, sex $\left(\mathrm{X}^{2}=.508, p=.476\right)$, and income $\left(\mathrm{X}^{2}=.272, p=.602\right)$. However, there was a positive and moderate association between age and time that hoarded animals $(r=.393, p=.024)$.

Regarding the participants' overall cognitive performance in the MMSE, the lowest total score was 9 points and the highest was $30(M=24.09, S D=5.36)$ points. About, $27.3 \%$ of participants displayed substandard performance in the MMSE (8.3\% in young adults group and $38.1 \%$ in older adults group).

In the Verbal Fluency test, only $9.4 \%$ of participants showed substandard performance and all deficits were presented by older adults. In the total score in the Rey Complex Figure copy section, $40 \%$ of the sample showing substandard performance $(33.3 \%$ in young adults group and $44.4 \%$ in older adults group), and in the total score of the Rey Complex Figure recall section $40 \%$ of participants showing substandard performance $(16.7 \%$ in young adults group and $55.6 \%$ in older adults group). In the WASI Similarities subtest, we found $73.3 \%$ of participants delivered substandard performance $(50.0 \%$ in young adults group and $83.3 \%$ in older adults group).

\section{Discussion}

Studies corroborate this finding and point out deficits in the executive performance of people with object hoarding disorder [21] and animal hoarding according a single case report [28]. Executive functions comprise several subcomponents, such as planning, logic reasoning, decision-making skills, cognitive flexibility, and inhibitory control. They allow people to control and regulate their information processing and behavior [20]. A 
Table 1 Sociodemographic and animal hoarding data of each participant

\begin{tabular}{|c|c|c|c|c|c|}
\hline Participant & Age (year) & Education (year) & Sex & Type of animal & Number of animals \\
\hline 1 & 58 & 11 & Female & Dogs and cats & 56 \\
\hline 2 & 72 & 11 & Female & Dogs and cats & 101 \\
\hline 3 & 62 & 10 & Female & Dogs & 80 \\
\hline 4 & 83 & 15 & Male & Dogs and cats & 71 \\
\hline 5 & 44 & 7 & Female & Dogs and cats & 32 \\
\hline 6 & 77 & 1 & Female & Dogs & 12 \\
\hline 7 & 76 & 7 & Female & Dogs and cats & 34 \\
\hline 8 & 69 & 9 & Female & Dogs and cats & 41 \\
\hline 9 & 53 & 8 & Male & Dogs and cats & 34 \\
\hline 10 & 61 & 8 & Male & Dogs & 40 \\
\hline 11 & 67 & 3 & Male & Dogs & 40 \\
\hline 12 & 65 & 13 & Female & Dogs and cats & 3 \\
\hline 13 & 49 & 16 & Female & Dogs and cats & 62 \\
\hline 14 & 53 & 11 & Female & Dogs and cats & 59 \\
\hline 15 & 78 & 11 & Female & Dogs and cats & 73 \\
\hline 16 & 62 & 9 & Female & Dogs and cats & 30 \\
\hline 17 & 36 & 11 & Female & Cats & 25 \\
\hline 18 & 73 & 16 & Female & Cats & 20 \\
\hline 19 & 38 & 4 & Male & Dogs and cats & 16 \\
\hline 20 & 29 & 16 & Male & Dogs and cats & 49 \\
\hline 21 & 64 & 3 & Female & Dogs & 60 \\
\hline 22 & 61 & 11 & Female & Dogs & 6 \\
\hline 23 & 56 & 8 & Female & Dogs & 65 \\
\hline 24 & 58 & 12 & Male & Dogs & 19 \\
\hline 25 & 60 & 11 & Female & Dogs and cats & 33 \\
\hline 26 & 71 & 4 & Female & Dogs & 20 \\
\hline 27 & 55 & 11 & Male & Dogs and ducks & 75 \\
\hline 28 & 56 & 16 & Female & Dogs and cats & 26 \\
\hline 29 & 63 & 10 & Female & Dogs and cats & 71 \\
\hline 30 & 63 & 7 & Female & Dogs and cats & 28 \\
\hline 31 & 64 & 5 & Male & Dogs & 11 \\
\hline 32 & 66 & 15 & Female & Cats & 47 \\
\hline 33 & 84 & 0 & Female & Dogs & 18 \\
\hline
\end{tabular}

potential explanation for this finding is that, because individuals with hoarding behaviors have these functions compromised, they would be unable to control their impulse of bringing more and more animals in and to keep an organized environment. Additionally, they would have trouble to plan according to their actual financial situation and keep a number of animals they could actually afford, in addition to ensuring the quality of their physical space.

Hartl et al. [15] found that individuals with hoarding behaviors show deficits related to their organization and planning skills when copying the Rey complex figure.
The elements of the figure were drawn in a disarranged manner. Studies point out that memory deficits are also positively associated with object hoarding disorder. Hence, memory difficulties added to exaggerated negative beliefs would reinforce the hoarding behavior [13, 15]. This study also found participants had trouble copying and recalling the Rey complex figure. Therefore, we can infer that, just as individuals with hoarding behaviors show deficits in their perception, organization, planning, and visual memory skills, individuals with animal hoarding behaviors also show these same deficits. This finding may help understand the hoarding behavior in 
Table 2 Sociodemographic and cognitive characteristics of participants

\begin{tabular}{|c|c|c|c|c|c|}
\hline & $n$ & $\%$ & $M$ & $S D$ & Minimum - maximum \\
\hline \multicolumn{6}{|l|}{ Gender } \\
\hline Female & 24 & 36,40 & - & - & - \\
\hline Male & 9 & 63,60 & - & - & - \\
\hline \multicolumn{6}{|l|}{ Marital status } \\
\hline Single & 22 & 66,67 & - & - & - \\
\hline Married & 4 & 12,12 & - & - & - \\
\hline Separate & 3 & 9,09 & - & - & - \\
\hline Widower & 4 & 12,12 & - & - & - \\
\hline \multicolumn{6}{|l|}{ Income ${ }^{a}$} \\
\hline 1 a 2 MS & 25 & 75,76 & - & - & - \\
\hline 3 a 4 MS & 3 & 9,09 & - & - & - \\
\hline 5 a 6 MS & 2 & 6,06 & - & - & - \\
\hline 7 a 8 MS & 1 & 3,03 & - & - & - \\
\hline More than $10 \mathrm{MS}$ & 2 & 6,06 & - & - & - \\
\hline \multicolumn{6}{|l|}{ MMSE (raw score) } \\
\hline All participants & 33 & - & 24,09 & 5,36 & $9,00-30,00$ \\
\hline Age group 20-59years & 12 & - & 27,08 & 2,81 & $21,00-30,00$ \\
\hline Age group $60+$ years & 21 & - & 22,38 & 5,76 & $9,00-30,00$ \\
\hline \multicolumn{6}{|l|}{ Verbal fluency (raw score) } \\
\hline All participants & 32 & - & 15,91 & 6,19 & $4,00-32,00$ \\
\hline Age group 20-59years & 12 & - & 18,17 & 4,67 & $11,00-26,00$ \\
\hline Age group $60+$ years & 20 & - & 14,55 & 6,69 & $4,00-32,00$ \\
\hline \multicolumn{6}{|c|}{ Rey complex figure - copy total (raw score) } \\
\hline All participants & 29 & - & 28,03 & 8,34 & $4,00-36,00$ \\
\hline Age group $20-59$ years & 11 & - & 31,86 & 4,28 & $24,00-36,00$ \\
\hline Age group $60+$ years & 18 & - & 25,69 & 9,40 & $4,00-36,00$ \\
\hline \multicolumn{6}{|c|}{ Rey complex figure - recall total (raw score) } \\
\hline All participants & 30 & - & 12,25 & 8,42 & $0,00-29,50$ \\
\hline Age group 20-59years & 12 & - & 17,46 & 7,84 & $4,00-29,50$ \\
\hline Age group $60+$ years & 18 & - & 8,78 & 7,02 & $0,00-25,50$ \\
\hline \multicolumn{6}{|l|}{ Similarities (raw score) } \\
\hline All participants & 30 & - & 24,30 & 11,63 & $0,00-41,00$ \\
\hline Age group 20-59years & 12 & - & 30,67 & 11,90 & $0,00-41,00$ \\
\hline Age group $60+$ years & 18 & - & 20,06 & 9,56 & $0,00-36,00$ \\
\hline
\end{tabular}

MMSE Mini Mental State Examination

${ }^{a} 1$ minimum salary refers to $B R L 788.00 /$ month

animal hoarding as it reinforces the hypothesis that organization, planning, and visual memory deficits would lead someone to lose track of the number of animals, which end up breeding in captivity. Additionally, perception deficits may lead individuals with animal hoarding behaviors to not see their animals' actual health status or their environment's conditions.

Cognitive decline occurs due to various biopsychosocial influences [2]. In this study, participants presented lower
MMSE performance when compared to other healthy older adults and elderly $[16,17]$. Reduction of the cognitive capacity can bring to the subject of damages and the tasks in daily activities [31]. We inferred that, in advanced ages, there will be a higher rate of people presenting cognitive deficits associated with animal hoarding compared to healthy people at the same ages.

Based on this study's results, we found that people with animal hoarding show deficits related primarily to 
their executive functions. Out of the variables investigated, age and schooling were more closely related to the participants' cognitive performance, as well as the number of animals accumulated. Due to differences with hoarding disorder, some researchers even propose the animals hoarding as a new disorder [9].

The findings by this study are the first of their kind given the literature lacks empiric studies measuring the cognitive performance of individuals with hoarding behaviors. As for limitations, we could point out that the sample is small and covered only the area of a city in the south of Brazil, which characterizes it as regional. In addition, it should be considered as a limitation of the study, the absence of analysis of other comorbid diagnoses. Another limitation is that it was conducted with a clinical sample yet to be investigated, the discussions and theoretical grounds were based on studies looking into people with object hoarding disorder. Thus, we suggest that further studies should be conducted, because this clinical condition remains largely unexplored by empirical studies. One more suggestion is including a healthy sample with the same demographic characteristics to make a comparison of the performance in all the test. The development of new studies will enable the development of therapeutic strategies to help the treatment and management of this problem, which translates into suffering for people, animals and their environment.

\section{Conclusions}

Our results showed that participants have cognitive deficits related to verbal concept formation, abstract verbal reasoning, and general intellectual skills. Their perception, visuoconstructional, visual memory, planning, and organization skills and problem-solving strategies were also compromised. Therefore, we can infer they have cognitive deficits related primarily to executive functions.

\section{Acknowledgements}

We thank the participants for their invaluable time

\section{Authors' contributions}

All authors contributed to the design and implementation of the research, to the analysis of the results and to the writing of the manuscript.

\section{Funding}

None.

Availability of data and materials

Data will be provided if requested.

\section{Ethics approval and consent to participate}

The project was approved by the PUCRS Ethics Committee (CEP-PUCRS) under CAAE: 44489715.8.0000.5336. The participants were contacted via home visits, and those who accepted to take part in the study signed an informed consent form.

Consent for publication

All authors consent publication.
Competing interests

None.

\section{Author details}

${ }^{1}$ Pontifícia Universidade Católica do Rio Grande do Sul - PUCRS, Av. Ipiranga, 6681, Building 11, 9th floor, Porto Alegre, RS CEP 90619-900, Brazil.

${ }^{2}$ Faculdade Meridional - IMED, Rua Senador Pinheiro, 304, Passo Fundo, RS CEP 99070-220, Brazil. '3niversidade Federal de Ciências da Saúde de Porto Alegre - UFCSPA, Rua Sarmento Leite, 245, Porto Alegre, RS CEP 90050170, Brazil. ${ }^{4}$ Facultad de Psicología, Universidad Católica de Valencia San Vicente Mártir, Valencia, Spain.

Received: 3 December 2019 Accepted: 10 February 2020

Published online: 24 February 2020

\section{References}

1. American Psychiatric Association. (2014). DSM-5: Manual diagnóstico e estatístico de transtornos mentais. Artmed Editora.

2. Argimon IIL, Lopes RMF, Terroso LB, Farina M, Wendt G, Esteves CS. Gênero e escolaridade: estudo através do miniexame do estado mental (MEEM) em idosos. Aletheia. 2012;38(39):153-61 Retrieved from http://www.periodicos. ulbra.br/index.php/aletheia/article/view/3369/2507.

3. Bertolucci, P. H., Brucki, S., Campacci, S. R., \& Juliano, Y. (1994). O mini-exame do estado mental em uma população geral: impacto da escolaridade. Arquivos de Neuro-psiquiatria, 52(1), 01-07.

4. Blom RM, Samuels JF, Grados MA, Chen Y, Bienvenu OJ, Riddle MA, et al. Cognitive functioning in compulsive hoarding. J Anxiety Disord. 2011;25(8): 1139-44. https://doi.org/10.1016/j.janxdis.2011.08.005.

5. Brucki SMD, Malheiros SMF, Okamoto $H$, Bertolucci PH. Normative data: category verbal fluency. Arq Neuropsiquiatr. 1997;55(1):56-61. https://doi. org/10.1590/S0004-282X1997000100009.

6. DiMauro J, Genova M, Tolin DF, Kurtz MM. Cognitive remediation for neuropsychological impairment in hoarding disorder: a pilot study. J Obsess-Compuls Relat Disord. 2014;3(2):132-8. https://doi.org/10.1016/j. jocrd.2014.03.006

7. Dozier ME, Bratiotis C, Broadnax D, Le J, Ayers CR. A description of 17 animal hoarding case files from animal control and a humane society. Psychiatry Res. 2019;272:365-8. https://doi.org/10.1016/j.psychres.2018.12. 127.

8. Elliott R, Snowdon J, Halliday G, Hunt GE, Coleman S. Characteristics of animal hoarding cases referred to the RSPCA in New South Wales, Australia. Aust Vet J. 2019;97(5):149-56. https://doi.org/10.1111/avj.12806.

9. Ferreira EA, Paloski LH, Costa DB, Fiametti VS, De Oliveira CR, de Lima Argimon II, et al. Animal hoarding disorder: a new psychopathology? Psychiatry Res. 2017;258:221-5. https://doi.org/10.1016/j.psychres.2017.08. 030.

10. Frost $\mathrm{RO}$, Patronek $\mathrm{G}$, Rosenfield E. A comparison of object and animal hoarding. Depress Anxiety. 2011a;28(10):885-91. https://doi.org/10.1002/da. 20826.

11. Frost RO, Tolin DF, Steketee $G$, Fitch $\mathrm{KE}$, Oh M. Indecisiveness and hoarding. Int J Cogn Ther. 2011b;4(3):253-62 Retrieved from https://www. researchgate.net/publication/270541285_Indecisiveness_and_Hoarding.

12. Grisham JR, Norberg MM, Williams AD, Certoma SP, Kadib R. Categorization and cognitive deficits in compulsive hoarding. Behav Res Ther. 2010;48(9): 866-72. https://doi.org/10.1016/j.brat.2010.05.011.

13. Hallion LS, Diefenbach GJ, Tolin DF. Poor memory confidence mediates the association between inattention symptoms and hoarding severity and impairment. J Obsess-Compuls Relat Disord. 2015;7:43-8. https://doi.org/10. 1016/j.jocrd.2015.10.003.

14. Hartl TL, Duffany SR, Allen GJ, Steketee G, Frost RO. Relationships among compulsive hoarding, trauma, and attention- deficit/hyperactivity disorder Behav Res Ther. 2005;43:269-76. https://doi.org/10.1016/j.brat.2004.02.002.

15. Hartl TL, Frost RO, Allen GJ, Deckersbach T, Steketee G, Duffany SR, Savage CR. Actual and perceived memory deficits in individuals with compulsive hoarding. Depress Anxiety. 2004;20(2):59-69. https://doi.org/ 10.1002/da.20010.

16. Irigaray TQ, Gomes Filho I, Schneider RH. Efeitos de um treino de atenção, memória e funções executivas na cognição de idosos saudáveis. Psicologia: Reflexão e Crítica. 2012;25(1):188-202. https://doi.org/10.1590/S010279722012000100023 
17. Kochhann R, Varela JS, Lisboa CSM, Chaves MLF. The mini mental state examination review of cutoff points adjusted for schooling in a large southern Brazilian sample. Dement Neuropsychol. 2010;4(1):35-41. https:// doi.org/10.1590/S1980-57642010DN40100006

18. Lezak MD, Howieson DB, Bigler ED, Tranel. Neuropsychological assessment. New York: Oxford University Press; 2013.

19. Mackin RS, Areán PA, Delucchi KL, Mathews CA. Cognitive functioning in individuals with severe compulsive hoarding behaviors and late life depression. Int J Geriatr Psychiatry. 2010;26(3):314-21. https://doi.org/10. 1002/gps.2531.

20. Martoni AT, Trevisan BT, Dias NM, Seabra AG. Funções executivas: relação entre relatos de pais, de professores e desempenho de crianças. Temas em Psicologia. 2016;24(1):173-88. https://doi.org/10.9788/TP2016.1-12.

21. Morein-Zamir S, Papmeyer M, Pertusa A, Chamberlain SR, Fineberg NA, Sahakian BJ, et al. The profile of executive function in OCD hoarders and hoarding disorder. Psychiatry Res. 2014;215(3):659-67. https://doi.org/10. 1016/j.psychres.2013.12.026.

22. Moshier SJ, Wootton BM, Bragdon LB, Tolin DF, Davis E, DiMauro J, Diefenbach GJ. The relationship between self-reported and objective neuropsychological impairments in patients with hoarding disorder. J Obsess-Compuls Relat Disord. 2016;9:9-15. https://doi.org/10.1016/j.jocrd.2016.01.002

23. Oliveira M, Rigoni M, Andretta I, Moraes JF. Validação do Teste Figuras Complexas de Rey na população brasileira. Avaliação Psicológica. 2004;3(1): 33-8 doi: http://pepsic.bvsalud.org/scielo.php?pid=S1677-047120040001 00004\&script=sci_abstract\&tlng=es.

24. Oliveira MDS, Rigoni MS. Figuras Complexas de Rey: teste de cópia e de reprodução de memória de figuras geométricas co mplexas. São Paulo: Casa do Psicólogo; 2010.

25. Paloski LH, Ferreira EA, Costa DB, del Huerto ML, de Oliveira CR, de Lima Argimon II, Irigaray TQ. Animal hoarding disorder: a systematic review. Psico. 2017;48(3):243-9. https://doi.org/10.15448/1980-8623.2017.3.25325.

26. Peña-Casanova J, Fombuena NG, Fullà. Test neuropsicológicos. Barcelona: Elsevier Masson; 2004

27. Raines, A. M., Oglesby, M. E., Unruh, A. S., Capron, D. W., \& Schmidt, N. B. (2014). Perceived control: A general psychological vulnerability factor for hoarding. Personality and Individual Differences, 56, 175-179.

28. Saldarriaga-Cantillo A, Rivas Nieto JC. Noah syndrome: a variant of Diogenes syndrome accompanied by animal hoarding practices. J Elder Abuse Negl. 2015;27(3):270-5. https://doi.org/10.1080/08946566.2014.978518.

29. Santos CS, Cerchiari EA, Alvarenga MR, Faccenda O, Oliveira MA. Avaliação da confiabilidade do Mini-Exame do Estado Mental em idosos e associação com variáveis sociodemográficas. Cogitare Enferm. 2010;15(3):406-12 https://www.redalyc.org/pdf/4836/483648972002.pdf.

30. Santos, S. A. E. N., 2009. Fluência verbal semântica e fonêmica: estudos psicométricos e normativos numa amostra de adultos idosos saudáveis. [Dissertação de Mestrado], Universidade de Coimbra. Retrieved from http:// hdl.handle.net/10316/15774.

31. Schlindwein-Zanini R. Demência no idoso: aspectos neuropsicológicos. Revista Neurociências. 2010;18(2):220-6 Retrieved from https://periodicos. unifesp.br/index.php/neurociencias/article/view/8482.

32. Strauss E, Sherman EMS, Spreen O. A compendium of neuropsychological tests: administration, norms and commentary. New York: Oxford University Press; 2006.

33. Timpano KR, Smith AM, Yang JC, Cek D. Information processing. In: Frost $\mathrm{S}$, editor. The oxford handbook of hoarding and acquiring. New York: Oxford University Press; 2014. p. 100-19.

34. Trentini, C. M., Yates, D. B., \& Heck, V. S. (2014). Weschler abbreviated scale of intelligence (WASI): Professional Manual. Psychology House, São Paulo.

35. Ung JE, Dozier ME, Bratiotis $C$, Ayers CR. An exploratory investigation of animal hoarding symptoms in a sample of adults diagnosed with hoarding disorder. J Clin Psychol. 2017;73(9):1114-25. https://doi.org/10.1002/jclp. 22417.

36. Wincze JP, Steketee G, Frost RO. Categorization in compulsive hoarding Behav Res Ther. 2007;45(1):63-72. https://doi.org/10.1016/j.brat.2006.01.012.

37. Woody SR, Kellman-McFarlane K, Welsted A. Review of cognitive performance in hoarding disorder. Clin Psychol Rev. 2014;34(4):324-36. https://doi.org/10.1016/j.cpr.2014.04.002

\section{Publisher's Note}

Springer Nature remains neutral with regard to jurisdictional claims in published maps and institutional affiliations.

Ready to submit your research? Choose BMC and benefit from:

- fast, convenient online submission

- thorough peer review by experienced researchers in your field

- rapid publication on acceptance

- support for research data, including large and complex data types

- gold Open Access which fosters wider collaboration and increased citations

- maximum visibility for your research: over $100 \mathrm{M}$ website views per year

At BMC, research is always in progress.

Learn more biomedcentral.com/submissions 